\title{
A IGREJA ADVENTISTA DO SÉTIMO DIA E A POLÍTICA PARTIDÁRIA APÓS A REDEMOCRATIZAÇÃO NO BRASIL: ABORDAGEM TEMÁTICA NA REVISTA ADVENTISTA
}

\author{
The Seventh-day Adventist Church and the partisan politics after redemocratization \\ in Brazil: thematic approach in the Revista Adventista
}

Kevin Willian Kossar Furtado ${ }^{1}$

\begin{abstract}
RESUMO
O presente trabalho, temática e objetivamente, aborda como a Revista Adventista - periódico de perfil teológico-doutrinário-jornalístico, que se identifica como órgão geral da Igreja Adventista do Sétimo Dia (IASD) brasileira - tratou da política partidária, em anos eleitorais, a partir da redemocratização e da volta das eleições diretas no Brasil. Em pesquisa documental por meio da busca refinada do termo "partidária" no acervo digitalizado da revista disponível na internet, foram selecionados cinco textos: um artigo com conceitos básicos para orientar a posição dos adventistas sobre a política; uma entrevista que trata da relação entre Igreja e Estado nos escritos de Ellen G. White, considerada profetisa pela IASD, e a responsabilidade civil dos membros da Igreja; um artigo que apresenta e comenta o documento Os adventistas e a política, preparado pela Divisão Sul-Americana da IASD; e dois artigos que retomam as orientações apresentadas no documento Os adventistas e a política. Os materiais foram analisados com o uso dos conceitos de memória, condições de produção, paráfrase e polissemia da análise do discurso. A memória discursiva adventista sobre política se baseia em referências bíblicas, escritos de Ellen G. White e no documento Os adventistas e a política. Os escritos whiteanos nortearam a produção da primeira sistematização de orientações políticas da IASD, base do documento Os adventistas e a política, que se destaca como guia do pensamento e posicionamento da Igreja Adventista, cujas condições de produção ocorreram em um contexto de polarização política no Brasil.
\end{abstract}

Palavras-chave: Política partidária. Revista Adventista. Igreja Adventista do Sétimo Dia. Eleições.

\begin{abstract}
The present work, thematically and objectively, addresses how Revista Adventista - a periodical with theological-doctrinal-journalistic profile, which identifies itself as the general organ of the Brazilian Seventh-day Adventist Church (SDAC) - dealt of the partisan politics, in electoral years, the starting from the redemocratization and the return of direct elections in Brazil. In a document research through the refined search of the term "partisan" in the magazine's digitized collection available on the internet, five texts were selected: an article with basic concepts to guide the position of Adventists on politics; an interview that deals the relationship between Church and State in the writings of Ellen G. White, considered a prophetess by the SDAC, and the civil responsibility of Church members; an article that presents and comments the document Adventists and politics, prepared by the South American Division of the Adventist Church; and two articles that takes up the guidelines presented in the document Adventists and politics. The materials were analyzed using the concepts of memory, production conditions, paraphrase and

\footnotetext{
${ }^{1}$ Pós-doutorando em Sociologia na Universidade Federal do Paraná (UFPR). Doutor em Teologia pela Pontifícia Universidade Católica do Paraná (PUCPR). Mestre em Ciências Sociais Aplicadas e bacharel em Jornalismo pela Universidade Estadual de Ponta Grossa (UEPG).

REVISTA RELEGENS THRÉSKEIA - 2021 - UFPR
} 
polysemy of discourse analysis. The Adventist discursive memory on politics is based on biblical references, writings by Ellen G. White, and in document Adventists and politics. White's writings guided the production of the first systematization of political orientations of the SDAC, basis of the document Adventists and politics, which stands out as guide of the thought and positioning of the Adventist Church, whose production conditions took place in a context of political polarization in Brazil.

Keywords: Partisan politics. Revista Adventista. Seventh-day Adventist Church. Elections.

\section{Introdução ${ }^{2}$}

O presente texto aborda como a Revista Adventista, órgão geral da Igreja Adventista do Sétimo Dia (IASD) no Brasil, editada pela Casa Publicadora Brasileira, editora oficial da Igreja Adventista no país, tratou da política partidária de 1988 a 2020 em anos eleitorais. O recorte selecionado justifica-se por compreender a redemocratização e a volta das eleições diretas no país. A seleção do material para análise se deu a partir de leitura flutuante e pesquisa documental (OLIVEIRA, 2007; CELLARD, 2008) de todos os números publicados no período selecionado através da busca refinada do termo "partidária" no acervo digitalizado da revista disponível na internet. Foram encontradas 23 menções em 17 textos. A busca do termo "partidária" e não por "política partidária" se deve porque o sistema da revista localiza com mais exatidão termos unitários. A busca por "política partidária" conduz a ocorrências que fogem do escopo deste texto. Isso justifica, também, porque outros termos como "política eleitoral", "política" e "eleição/eleições" não foram pesquisados. ${ }^{3}$

Foram excluídos da análise os textos em que o termo "partidária" não estava relacionado com a política eleitoral ou eleições, o que resultou na delimitação do corpus em cinco textos: um artigo com conceitos básicos para orientar a posição dos adventistas sobre a política; uma entrevista que trata da relação entre Igreja e Estado nos escritos de Ellen G. White - considerada profetisa pela IASD - e a responsabilidade civil dos membros da Igreja; um artigo que apresenta e comenta o documento Os adventistas e a política, preparado pela Divisão Sul-Americana (DSA) da IASD; e dois artigos que retomam as orientações apresentadas no documento $O s$ adventistas e a política. O exame dos materiais escolhidos se pautou nos conceitos de memória,

\footnotetext{
${ }^{2}$ Uma versão preliminar deste trabalho foi apresentada no III Simpósio Internacional/16 ${ }^{\circ}$ Simpósio Nacional da Associação Brasileira de História das Religiões - Política, religião e diversidades: educação e espaço público, realizado na Universidade Federal de Santa Catarina em outubro de 2018.

${ }^{3}$ Não obstante, reconhece-se que a pesquisa, sobretudo, dos termos "política eleitoral" - ou "eleitoral" - e "eleição/eleições" poderia agregar material para análise, o que não foi efetuado pelos limites do presente texto. Fica, no entanto, o desafio para investigações ulteriores.
} 
condições de produção, paráfrase e polissemia da análise do discurso (ORLANDI, 2009, PÊCHEUX, 1999).

\section{A igreja Adventista e a Revista Adventista}

\subsection{Nascimento e estrutura organizacional da Igreja Adventista}

A Igreja Adventista se origina de um grupo de cristãos que anunciava a segunda vinda de Jesus à Terra durante a década de 1840 (SCHWARZ; GREENLEAF, 2009, p. 23-29), no contexto dos movimentos messiânicos do século XIX, nos Estados Unidos, cuja principal característica era o inconformismo com as denominações religiosas existentes (OLIVEIRA FILHO, 2004, p. 157). A IASD parte diretamente do movimento milerita, que abrigava cristãos de diferentes igrejas, liderado por Guilherme Miller (1772-1849). Após a realização de um estudo sistemático e completo das profecias bíblicas, Miller alegava que Jesus voltaria à Terra por volta de 1843. A partir de outros cálculos proféticos, o pastor milerita Samuel S. Snow determinou que o dia 22 de outubro de 1844 seria a data exata do evento, que não ocorreu, o que ficou conhecido como "o grande desapontamento" (SCHWARZ; GREENLEAF, 2009, p. 35-56). Um dos grupos desapontados se organiza e, em 21 de maio de 1863, funda a IASD (SCHWARZ; GREENLEAF, 2009, p. 94).

A IASD possui 28 crenças fundamentais, a maioria compartilhadas com outros cristãos, como a Trindade, a salvação pela fé em Jesus Cristo e a autoridade das Escrituras (BEACH, 2005, p. 609; NAVARRO, 2006). Ela se define como uma organização religiosa protestante conservadora. Seus membros são reconhecidos por observarem o sábado, destacarem o cuidado com a saúde e pela realização de atividades missionárias (VYHMEISTER, 2011, p. 1). Conforme números do Escritório de Arquivos, Estatísticas e Pesquisa (ASTR, na sigla em inglês) da Associação Geral da IASD de 30 de junho de 2018, a Igreja possui mais de 21 milhões de membros no mundo. ${ }^{4}$ Segundo dados de 2020 da ASTR, no Brasil são mais 1.729.459 membros em 9.697 igrejas, o que torna o país com o maior número de adventistas no mundo. ${ }^{5}$

A estrutura organizacional da IASD conta com igrejas locais, que tanto podem ser chamadas de grupo ou Igreja, que se dividem em uma série de departamentos, liderados por membros locais, escolhidos pela Comissão da Igreja local. As comissões dos grupos e igrejas

\footnotetext{
4 Disponível em: <https://noticias.adventistas.org/pt/noticia/institucional/adventistas-ao-redor-do-mundoultrapassam-os-21-milhoes/>. Acesso em: 3 ago. 2021.

${ }^{5}$ Disponível em: <https://documents.adventistarchives.org/Statistics/ASR/ASR2021.pdf>. Acesso em: 3 ago. 2021. 
escolhem, nas suas congregações, representantes que se reúnem para escolher os líderes das associações ou missões locais. No Brasil, uma associação/missão costuma abranger, no máximo, um estado da federação (FURTADO, 2017, p. 147-148). As associações se agrupam da mesma forma que as igrejas locais para formarem as uniões que, no caso brasileiro, podem aglutinar dois a três estados e que, em outros lugares do mundo, podem abranger todo um país (SEAMAN, 2011, p. 33-34). Por fim, as formam as divisões. No mundo, são 13. Todas as divisões são representadas pela Associação Geral, que coordena a Igreja Adventista no mundo.

\subsection{A Revista Adventista no Brasil}

Após o uso voltado ao universo religioso dos tipos móveis de metal inventados por Johannes Gutenberg, em 1455, a partir da Reforma protestante comandada por Martinho Lutero em 1517, a partir do século XVI a relação entre imprensa e religião se estreitou conforme a popularização de novas formas de comunicação, em uma relação, na maioria das vezes, de negação inicial dos fenômenos e posterior aceitação e apropriação (FONSECA; MARIN, 2020, p. 9-10). ${ }^{6}$

Na esfera religiosa brasileira, o caso mais emblemático de apoderamento de meios de comunicação ocorre com as igrejas pentecostais e neopentecostais, através do uso de panfletos, livros, jornais, revistas, canais de rádio e TV. Esses usos não se restringem às instituições cristãs ou ao Ocidente, mas são efetuados por líderes budistas, muçulmanos, judeus, hindus, religiões indígenas e africanas. Por isso, pesquisadores como Haun Saussy defendem uma perspectiva de análise em que a história das religiões se associe à história da mídia. Já para Stewart Hoover, a compreensão da religião em sociedade deve passar pela análise das relações dos grupos religiosos com os meios de comunicação (FONSECA; MARIN, 2020, p. 11).

A história da imprensa adventista brasileira começa em 1904 com a publicação d' $O$ arauto da verdade - que De Benedicto e Borges (2006, p. 8) apontam como ocorrido em 1900. Em 1906 surge a Revista Trimensal, hoje Revista Adventista, nome adotado em março de 1931 (SCHEFFEL, 2006, p. 17). Nas capas, ela passou a ser identificada como órgão oficial da Igreja brasileira dos adventistas do sétimo dia, designação que continuou até 1974. A partir de 1975, como órgão geral da denominação em terras brasileiras (DE BENEDICTO; BORGES, 2006, p. 8) - cuja informação aparece, atualmente, no expediente de cada edição. A publicação conta com um acervo digital ${ }^{7}$ que abriga todos os números do periódico, desde a sua primeira edição,

\footnotetext{
${ }^{6}$ Processo também observado na Igreja Adventista, conforme demostra Novaes (2016).

${ }^{7}$ Disponível em: 〈https://acervo.cpb.com.br/ra〉. Acesso em: 3 ago. 2021. REVISTA RELEGENS THRÉSKEIA - 2021 - UFPR
} 
em 1906, de onde parte a pesquisa de fontes do presente trabalho. A atualização do acervo ocorre depois da publicação da versão impressa. O último dado de tiragem está disponível no expediente da edição de abril de 2020, que aponta 146 mil exemplares. A revista conta, também, com um site homônimo ${ }^{8}$ que republica textos da versão impressa.

A Revista Adventista noticia os acontecimentos mais significativos que envolvem os adventistas e o cristianismo no Brasil e no mundo (FURTADO, 2019, p. 275). Scheffel (2006, p. 17) aponta que o periódico "não é uma publicação aberta para o livre debate de [ideias. A revista] tem uma linha de sustentação doutrinária e não pode abrir espaço para suscitar dúvidas e controvérsias. Procura servir a Igreja toda, e não apenas a um segmento.” Para o pastor Rubens Lessa, que ocupou por mais tempo a função de redator-chefe da publicação, no período de abril de 1976 a janeiro de 1982 e de abril de 1985 até maio de 2014, entre os um dos principais objetivos da revista se configura em "contribuir para a unidade da [Igreja Adventista], fortalecer a vida espiritual dos leitores, ampliar-lhes o conhecimento doutrinário e teológico e defender a Igreja das distorções doutrinárias e teológicas” (DE BENEDICTO; BORGES, 2006, p. 10). Por conta desses elementos, Furtado (2019, p. 279) mostrou que, na perspectiva da análise do discurso, as condições de produção discursiva no periódico estão circunscritas em uma lógica de manutenção dos sentidos doutrinais e simbólicos dos temas que a revista aborda, em conformidade com o pensar teológico adventista.

\section{Evangélicos e a polarização política no brasil}

No Brasil contemporâneo cresceram os atravessamentos entre religião e política. Os conflitos de interpretações religiosas são característicos da formação do Estado republicano brasileiro, em 1889, que, em tese, se mantém neutro em relação às instituições religiosas. $\mathrm{O}$ país observa a investida de personalidades religiosas, sobretudo católicas e evangélicas, "na construção de uma patrulha ideológica nos postos do Estado brasileiro e a sua ocupação efetiva" em os níveis e nos três poderes da República (PY; SILVEIRA; FREITAS, 2021, p. 8).

Os evangélicos derivam do protestantismo, segmento do cristianismo que já foi interpretado na história como alicerce da modernidade cultural e econômica, mas que no início do século XX, após cismas fundamentalistas e pentecostais, sobrelevaram o liberalismo, espalharam-se pelo mundo e culminaram na nova direita cristã. Na América Latina, os evangélicos transformaram o campo religioso por meio de bancadas parlamentares e partidos

\footnotetext{
${ }^{8}$ Disponível em: <http://www.revistaadventista.com.br/>. Acesso em: 3 ago. 2021. REVISTA RELEGENS THRÉSKEIA - 2021 - UFPR
} 
com um ativismo conservador, expresso, por exemplo, nas eleições presidenciais de 2018 no Brasil, na defesa de valores como a "família", a "vida", a conformação do ordenamento jurídico aos "valores morais" dos cristãos, através da militância contra temas como o aborto, políticas igualitárias e anti-homofóbicas, a educação sexual e a suposta doutrinação ideológica e de "gênero" nas escolas (MARIANO; GERARDI, 2019, p. 63).

Na relação entre religião e política no Brasil na última década, a radicalização tem ditado a governabilidade institucional e a participação popular nas relações de poder, ao mesmo tempo em que agentes religiosos ganham mais espaço no cenário político. Os grupos religiosos estão estreitando relações entre o conservadorismo político e o cristianismo, o que tem gerado uma politização reativa que não se restringe "a acionar as moralidades religiosas como fiadoras da gestão da res publica, mas também recorrem a um amplo instrumental secular, composto de mecanismos jurídicos e legislativos.” (CARRANZA; SANTOS; JÁCOMO, 2021, p. 5).

A política brasileira vivencia um momento de guerra cultural, termo que caracteriza os discursos pautados em temas morais como, além dos supracitados, legalização das drogas e sistema penal, que subordinam questões de ordem econômica e sociais em uma concepção de mundo punitiva, e que reverberam no debate público (GALLEGO; ORTELLADO; MORETTO, 2017, p. 36). As guerras culturais de orientação religiosa ganharam importância crescente na opinião pública e na disputa eleitoral brasileira, e se tornarem a pauta principal no processo eleitoral de 2018 (DUTRA; PESSÔA, 2021, p. 233). O cenário político brasileiro fomenta a oposição "nós contra eles", fenômeno observado principalmente em comportamentos "descorteses" que marcam as redes sociais atualmente (LIMA, 2020, p. 63).

Nesse cenário, a Igreja Adventista busca se situar com neutralidade. Em um dos únicos trabalhos publicados no Brasil que discute política no contexto adventista, Rocha (2006) esclarece que a IASD deve descartar participar da política partidária. A posição oficial da Igreja Adventista é apolítica. "Pastores e líderes da Igreja, em funções pastorais distritais ou em outro nível da estrutura organizacional da denominação, farão certo em precaver-se de qualquer manifestação de apoio em nome da Igreja a um determinado candidato em detrimento de outros." (ROCHA, 2006, p. 18).

Observa-se que a Igreja Adventista se constitui como um grupo religioso pouco estudado nas Ciências Humanas e Sociais no Brasil, o que a torna estranha até mesmo ao campo religioso, em detrimento à grande quantidade de estudos sobre religiões afro-brasileiras, neopentecostais (PAIVA JÚNIOR, 2012, p. 1) e o catolicismo (RIBEIRO, 2007, p. 117). Para Fonseca (2008, p. 91), a invisibilidade acadêmica da IASD se deve pelo estereótipo formado 
contra os adventistas e reforçado pela baixa participação de seus membros em atividades interconfessionais. Apenas a partir de 1972, dissertações e teses começaram a ser produzidas sobre a Igreja Adventista nas universidades brasileiras (FUCKNER, 2012, p. 163). Como exemplo disso, na revisão de literatura feita para a realização deste trabalho, além do artigo de Rocha (2006), encontramos apenas mais uma produção que relaciona os adventistas com a política. Nela, Barbosa (2012) discute as razões da recusa da IASD em se inserir na política e permanecer apartidária.

\section{A política partidária na Revista Adventista}

Para análise da política partidária na Revista Adventista partimos da pesquisa documental, que investiga documentos originais que ainda não receberam tratamento analítico, ou seja, fontes primárias, como revistas, entre outras fontes. As fontes primárias são dados originais, que possibilitam uma relação direta com os fatos que se quer analisar e o pesquisador (OLIVEIRA, 2007). O uso de documentos em pesquisa permite que se acrescente o fator tempo na compreensão do social. Assim, favorece a compreensão dos processos de maturação de grupos, conceitos e comportamentos (CELLARD, 2008).

Seguimos com a análise do discurso, em que a memória discursiva forma a base semântica de um discurso. Seu funcionamento acontece através da repetição de enunciados que formam uma regularidade discursiva, que utiliza-se de significados pré-construídos conservados nas séries enunciativas (PÊCHEUX, 1999). As condições de produção abrangem os sujeitos e as situações e incluem, em sentido estrito, as circunstâncias da enunciação, o contexto presente. Já de forma ampla, abrigam o contexto socio-histórico, ideológico e o imaginário criado pelas instituições sobre o já-dito e a memória (ORLANDI, 2009).

A paráfrase se configura como um processo por meio do qual em todo dito existe algo que se mantém, se repete, a memória, que sempre retorna aos mesmos espaços do dizer. $\mathrm{Na}$ paráfrase se criam diferentes formulações do mesmo dizer sedimentado. Ela representa a estabilização, ao contrário da polissemia, que representa o deslocamento, o rompimento dos processos de significação. A construção do discurso se pauta na tensão entre o mesmo e o diferente. Embora em toda expressão ocorram alterações na estrutura de filiação dos sentidos, trata-se de palavras já ditas. Na relação entre paráfrase e polissemia, entre o mesmo e o diferente, entre o já dito e o que se dirá, os sujeitos e os sentidos se movimentam, realizam seus percursos e se significam (ORLANDI, 2009). A seguir, discutimos como a Revista Adventista 
tratou da política partidária, em anos de eleitorais, a partir da redemocratização e da volta das eleições diretas no Brasil.

\subsection{A IASD como organização apolítica, candidatos e eleitores adventistas}

Em Os adventistas e a política (TIMM, 2006, p. 12-15), Alberto R. Timm, que, época, ocupava o posto de professor de Teologia Histórica do Centro Universitária Adventista de São Paulo (UNASP), uma das principais instituições de ensino superior da IASD no mundo - e a mais importante do Brasil, e dirigia o Centro de Pesquisas Ellen G. White brasileiro, apresenta como a Igreja Adventista compreende a candidatura de seus membros a cargos políticos através de eleições públicas e fornece orientações para a escolha de representantes através do voto.

Aciona-se a memória discursiva adventista através de dois textos de Ellen G. White, figura de carisma profético e umas das fundadoras da Igreja Adventista, que servem de base para o entendimento da denominação sobre processos políticos eletivos. No capítulo Nossa atitude quanto à política do livro Obreiros evangélicos (WHITE, 2007c, 351-355) e em Testemunho especial acerca de politica, capítulo do Fundamentos da educação cristã (WHITE, 2007a, p. 415-425), são dadas, especificamente, orientações sobre o não envolvimento de obreiros denominacionais em questões políticas. Não obstante, Timm formula, a partir dos fragmentos das obras whiteanas supracitadas, "alguns conceitos básicos sobre a posição dos adventistas como cidadãos, candidatos e eleitores políticos.” (TIMM, 2006, p. 13). Em um processo ao mesmo tempo parafrástico e polissêmico, o teólogo se serve do já dito e o a se dizer na tradição adventista.

Três princípios fundamentais norteiam a posição da IASD sobre política. O primeiro deles é a separação entre Igreja e Estado, em que cada qual deve buscar cumprir suas atribuições sem ultrapassar a esfera de ação da outra. "A Igreja crê que só poderá preservar esse princípio por meio de uma postura denominacional apolítica, não se posicionando nem a favor e nem contra quaisquer regimes ou partidos políticos.” (TIMM, 2006, p. 13, grifo do autor). Timm (2006, p. 15) reitera que a IASD "sempre manteve uma posição oficial apolítica de não se posicionar a favor ou contra qualquer regime ou partido político", postura que deve ser mantida em todos os níveis da organização e nas diferentes instituições da Igreja, incluindo as congregações locais, num compromisso que atinge principalmente seus obreiros assalariados, que não estão autorizados a usar nenhum púlpito ou reunião oficialmente promovida pela denominação para levantar qualquer bandeira política. 
A memória discursiva não só adventista, a partir do já dito por Ellen G. White, mas de um valor - supostamente, ao menos - admitido por diferentes grupos cristãos, parafraseia-se na definição de uma posição "apolítica" e ganha novas significâncias ao ser ampliado e delimitado, pois ultrapassa a dimensão vaga da Igreja em si, para dever ser obedecido por todas as instituições dela dependentes, as igrejas locais - o que implica a adesão dos leigos - e o corpo profissionalmente vinculado à organização.

Para Timm (2006, p. 13), os ensinamentos de Cristo e dos apóstolos servem de referência para a Igreja evitar fazer militância política institucional. A IASD entende que o cristianismo apostólico desempenhava sua missão evangélica sem se revoltar contra as estruturas opressoras do Império Romano e que, ao Jesus afirmar que seu reino "não é deste mundo", implicava a seus "ministros" não levantar bandeiras políticas (Jo 18,36). Por conseguinte, para os adventistas, qualquer compromisso político ou partidário atrapalha a pregação do "evangelho eterno" a todos os seres humanos (Mt 24,14; Ap 14,6), uma das bases do ser adventista. Timm usa do que pretende ser uma memória discursiva oriunda da base do cristianismo: os ensinos de Jesus, de seus primeiros discípulos e a tradição apostólica. Em privilégio à polissemia do discurso, o teólogo elabora que os preceitos para o cumprimento da missão cristã e a busca de um reino transcendente inibem a manifestação e atuação política, passageira, efêmera, em contraste à salvação eterna.

O segundo princípio parte do pressuposto de que o nível da justiça social de um país está em equivalência ao nível de justiça de cada cidadão, e que este provém do interior de cada pessoa. Assim, no reconhecimento das "dimensões sociais do pecado", a Igreja Adventista apoia e participa de projetos sociais e educacionais que melhoram a vida comunitária, conquanto não conflitem com os princípios defendidos pela denominação. "No entanto, a Igreja não participa de quaisquer greves e passeatas de índole política e partidária que acabariam comprometendo sua postura apolítica.” (TIMM, 2006, p. 13). Para resolver o dilema da Igreja que se identifica como apolítica, mas necessita atuar em um mundo que carece de justiça, a IASD reelabora, em senso polissêmico, a possibilidade de ação pública e social de seus membros sem depender da política partidária, através da participação em projetos sociais e educacionais.

E, por fim, o terceiro princípio se situa no entendimento de que cada cristão-adventista carrega uma dupla cidadania; primeiramente, como cidadão do reino de Deus, mas, também, cidadão de seu país de origem. Por consequência, a Igreja entende que seus membros devem, ao exercer sua cidadania terrestre, se pautar "nos princípios cristãos de respeito ao próximo". 
Embora desaprove situações de injustiça e exploração social, a IASD "procura se relacionar respeitosamente com o governo civil e os partidos políticos de cada país em que exerce suas atividades, sem com isso comprometer os princípios bíblicos." (TIMM, 2006, p. 13). A Igreja aparenta entender que sua postura apolítica parece contraditória com seu senso de transformar e melhorar a realidade. Para tanto, usa da memória discursiva do cristianismo de respeito a todas as pessoas para legitimar uma relação neutra, mas pacífica com os poderes constituídos.

A Igreja Adventista, ao interpretar o texto bíblico de Marcos 12,17, de dar "a César o que é de César e a Deus o que é de Deus", compreende que ali se expõe o princípio de que ser cristão não implica desobrigação para com os deveres civis, e que o Novo Testamento - em passagens como Romanos 13,1-7; Tito 3,1-2; e I Pedro 2,13-17 - apresenta diversas orientações sobre o "dever cristão de honrar os governos civis como instituídos por Deus" (TIMM, 2006, p. 13). Apenas quando os governantes obrigam os cristãos a desobedecer o que consideram ser leis divinas, é que os adventistas podem expressar desacordo - baseados na indicação de Atos 5,29, que indica: "antes, importa obedecer a Deus do que aos homens" -, defende Timm. Mais uma vez, no que compreende ser uma memória discursiva legítima dos ensinos cristãos e da tradição apostólica, a IASD pontua que o comportamento de seus membros deve se nortear por obrigações civis e de respeito aos governantes, mas que impera a obediência divina, sobretudo nos contextos em que governos possam vir a fazê-lo descumprir os mandamentos divinos.

Considera-se que ocupar cargos políticos está entre os direitos de todo cristão-adventista no exercício de sua cidadania (TIMM, 2006, p. 13). Mesmo que a IASD não estimule nem desencoraje a candidatura política de seus membros, ela entende que a sociedade pode ser beneficiada pelo bom exemplo de alguns políticos adventistas que participam do processo eleitoral de forma honesta e exercem seus mandatos de maneira digna, sem comprometerem princípios bíblicos. Destaca-se o quanto o trabalho de adventistas eleitos pode favorecer a Igreja. "A influência positiva de políticos adventistas tem sido decisiva, em vários países, para o estabelecimento de legislações que facilitem a observância do sábado.” (TIMM, 2006, p. 14). O trecho revela as condições de produção do discurso adventista sobre a política partidária: por ser uma minoria religiosa em diversos países, as possibilidades de garantir o seguimento de seus valores identitários, como a guarda do sábado, valida as ações dos membros que gerem autobenefícios.

A IASD orienta que os candidatos adventistas se portem, no processo eleitoral-político, do seguinte modo: 
(1) sem assumir posturas ideológicas e partidárias contrárias aos princípios cristãos; (2) sem se valer de recursos financeiros inapropriados; (3) sem prometer o que não possa cumprir; (4) sem denegrir [sic] a reputação de outros candidatos igualmente honestos; (5) sem se envolver com coligações não condizentes com a fé cristã-adventista; (6) sem jamais comprometer a observância do sábado em suas campanhas; e (7) sem minimizar seu compromisso pessoal com o estilo de vida adventista em coquetéis e confraternizações sociais. (TIMM, 2006, p. 14).

O sentido discurso da atuação dos adventistas que participam de disputas políticoeleitorais usa do fenômeno da produtividade do processo parafrástico, que produção novos discursos a partir do já existente: os membros devem se furtar de práticas ilegais ou opostas aos valores cristãos como usar recursos financeiros impróprios, atuar em coligações que não defendem os mesmos princípios da IASD, desrespeitar o sábado e a dietética adventista.

Recomenda-se que as programações oficiais de qualquer congregação adventista não sejam usadas como palanque político que afete a postura apolítica da denominação e que os candidatos da Igreja, ao usarem do púlpito para pregar, jamais falem de política (TIMM, 2006, p. 14).

O princípio básico indicado aos adventistas para a escolha de seus representantes "é sempre votar em candidatos cuja ideologia, crenças, estilo de vida e propostas políticas estejam mais próximos dos princípios adventistas." Considera-se que os princípios mais importantes são: defesa da "liberdade religiosa, separação entre Igreja e Estado, observância do sábado, conduta moral, temperança cristã, apoio ao sistema educacional privado mantido pela Igreja, e a tentativa de melhorar a qualidade de vida das classes moral e economicamente desfavorecidas." (TIMM, 2006, p. 14). Além da paráfrase, novamente aparecem as condições de produção do discurso e as intenções da Igreja nas disputas políticas adventista. Observa-se que ela recomenda que seus membros apoiem aqueles políticos que defendem majoritariamente crenças e projetos exclusivos da Igreja, como a observância do sábado e o seu sistema de ensino.

A Igreja lembra (TIMM, 2006, p. 15), no entanto, que na escolha de candidatos deve-se evitar àqueles que justificam os meios pelos fins. Aquele candidato, embora sem compromisso com os princípios supracitados, que promete benefícios políticos ou financeiros para a denominação não deve ser tolerado. O compromisso com os princípios adventistas deve estar acima de qualquer benesse individual ou coletiva que possa ser oferecida. Em uma tensão entre paráfrase e polissemia, o discurso adventista não ressalta, apenas, os benefícios de atuações políticas ao seu favor. Em um deslocamento dos processos de significação até então vistos, promessas de vantagens financeiras por políticos são reprovadas pela Igreja. 
No tocante à escolha de seus representantes, os membros da Igreja Adventista são aconselhados a "votar conscientemente nos candidatos que melhor refletem os ideais adventistas." Considera-se que a escolha dos representantes políticos se constitui em uma afirmação do ser adventista, quando se expressa que o "voto de cada adventista deveria ser um testemunho autêntico a favor da liberdade religiosa que facilite o cumprimento da missão adventista." Complementa-se que tal escolha "não deveria ser tanto por partido político, mas pela ideologia e os valores pessoais de cada um" (TIMM, 2006, p. 15). Entre a membresia, pede-se que não se rejeite os adventistas que se candidatam a algum cargo eletivo, ao menos que tais se portem de modo indigno ou não apresentem um plano de governo adequado.

Não obstante ao indicado anteriormente, as condições de produção regem o tom do discurso ao privilegiar o contexto ideológico e o imaginário da Igreja de que seus membros devem escolher representantes políticos que se alinham aos projetos adventistas que colaborem para a execução de seus planos missionários.

\subsection{Dupla cidadania dos cristãos}

O segundo texto analisado, Dupla cidadania (LIMA, 2010, p. 6-7), de autoria de Wendel Lima, se constitui de uma entrevista feita com o pastor Márcio Costa, então professor de Teologia da Faculdade Adventista da Amazônia, aborda a relação entre Igreja e Estado conforme exposta nos escritos de Ellen G. White e a responsabilidade civil dos adventistas. A tese doutoral em Teologia do pastor, realizada na Andrews University, a mais privilegiada instituição de ensino superior da IASD, discutiu a relação da Igreja com o Estado nos escritos whiteanos.

$\mathrm{Na}$ entrevista, Costa explica como o conceito de um grande conflito entre forças do bem e do mal orientou a visão de Ellen G. White sobre a relação entre política e opinião; Costa opina, também, sobre "o posicionamento ideal dos adventistas quanto às questões civis." (LIMA, 2010, p. 6).

Nos primeiros anos do adventismo, a relação entre Igreja e Estado era vista em termos de separação das duas instâncias, por conta das implicações em termos de liberdade religiosa, o que sempre foi uma preocupação dos adventistas. A IASD herdou tal cuidado dos grupos de onde vieram os líderes que a fundaram, o movimento milerita e a Conexão Cristã. Costa esclarece que, no entanto, o desapontamento de 1844 e a compreensão profética desenvolvida, que apontava os Estados Unidos como uma das bestas do Apocalipse, ou seja, com significativa 
influência e atuação nos acontecimentos finais da história do mundo, alargaram a indisposição adventista para com o Estado (LIMA, 2010, p. 6).

Quanto à candidatura de adventistas a cargos públicos, Costa verificou nos escritos de Ellen G. White que ela era totalmente favorável e aconselhava os jovens adventistas a sonhar em ocupar cargos e posições de influência. Porém, ela advertia ${ }^{9}$ que

a religião deve ser o esteio de todas as decisões. Não pode haver incoerência entre o exercício da função e a prática da fé. Para ela, é a fidelidade às crenças bíblicas que pode levar um político adventista à notoriedade, e não a barganha dos seus princípios. (LIMA, 2010, p. 7, grifo nosso).

O tensionamento entre paráfrase e polissemia aparece no discurso de Costa na entrevista ao, respectivamente, voltar ao mesmo dito sedimentado da defesa da religiosidade como parâmetro para as escolhas políticas dos adventistas, e ao realizar um deslocamento discursivo quando ressalta o incentivo à participação política da juventude. Embora considere-se um elemento presente na memória discursiva adventista, por se tratar de uma recomendação de uma figura de carisma no adventismo, apresenta-se tal ponto enquanto polissêmico por romper com o padrão discursivo apolítico da IASD.

Para o voto em candidatos não adventistas, Costa usa um exemplo para demonstrar como a questão se apresenta em Ellen G. White: se entre dois candidatos, um defende o casamento homossexual, a venda indiscriminada de bebidas alcoólicas e o aborto, ao passo que o outro se mostra conservador em relação a questões morais, os adventistas devem escolher o último. "Se assuntos morais são o divisor de águas da eleição, devemos nos posicionar." (LIMA, 2010, p. 7). Caso tais temas fossem levados a plebiscito, Ellen G. White diz ser permitido, caso necessário, que os membros participem da consulta pelo voto no sábado, considerado dia sagrado e separado para exercer adoração ao divino e descanso das atividades seculares. Por isso, o voto é considerado "um dispositivo que a democracia nos dá de representar a vontade de Deus. Logo, [os adventistas não deveriam] eleger candidatos moralmente intemperantes, desequilibrados, de posicionamentos contrários à Bíblia." (LIMA, 2010, p. 7, grifo nosso).

Aqui, a paráfrase da discursiva adventista em pautas que envolvem moralidade legitima um comportamento concessório em um valor fundamental para o sentido de ser adventista, a observância sabática. Por uma nova formulação de dizeres sedimentados, abre-se uma brecha, uma adaptação no cumprimento de um dever tido como sagrado para representar, justamente, vontade divina, através da apropriação de um dispositivo do processo democrático.

${ }^{9}$ Ver White (2007a, p. 70-72).

REVISTA RELEGENS THRÉSKEIA - 2021 - UFPR 
Costa esclarece, adiante, que Ellen G. White se posiciona contra o proselitismo político na Igreja. A razão apresentada para tanto está no fato de que, se determinado político fosse apresentado aos membros como boa opção ao voto, alguém certamente discordaria e geraria divisão entre os fiéis. "O voto é um direito do cidadão e a igreja não se opõe a que o membro o exerça, desde que reserve essa decisão à vida privada e não faça proselitismo político na Igreja.” (LIMA, 2010, p. 7). Por isso, recomenda-se aos candidatos, mesmo que adventistas, que não usem o púlpito da Igreja durante a campanha, para que não se associe a pessoa com suas pretensões políticas, ainda que a mensagem apresentada não tenha relação com o tema política. ${ }^{10}$ Outra vez, se visualiza uma tensão entre paráfrase e polissemia no discurso. Pela paráfrase, ao direito do cristão de participação no processo político o dito retorna à memória na privação do proselitismo nos templos. Já pela polissemia, há uma alteração na estruturação do discurso em Costa, que contrapõe o recomendado por Timm (2006, p. 14) no tocante à presença de candidatos nos púlpitos da IASD. Enquanto em Timm não há restrições para que candidatos usem o púlpito da Igreja, desde que não tratem de política, em Costa orienta-se vedar que eles se expressem no período eleitoral.

Questionado se a Igreja pode se filiar a partidos políticos, Costa aponta que ela precisa ter independência ideológica e que sua prioridade não é com uma agenda externa, pois ela já possui uma missão específica. Ele cita, como exemplo da postura dos adventistas, o envolvimento no caso da proibição da venda de bebidas alcoólicas na década de 1860, nos Estados Unidos. Ellen G. White, outros líderes e membros da Igreja, ao invés de defender uma visão politizada da questão e pressionar os políticos, "subiram aos púlpitos para defender o aspecto bíblico da questão, que vê na reforma de saúde um processo de restauração da imagem de Deus.” (LIMA, 2010, p. 7). Por meio da paráfrase, o sentido sedimentado da primazia dos "valores bíblicos", preponderante para os adventistas na consideração de questões discutidas e decididas na esfera política, autentica uma militância intraeclesial sem, no entanto, politizar as pautas.

Porém, quando uma discussão política nos Estados Unidos tratou da obrigatoriedade da guarda do domingo, "os adventistas se alinharam aos vendedores de bebidas alcoólicas que também desaprovavam, por interesses comerciais, a lei dominical.” (LIMA, 2010, p. 7). Embora expresse que a Igreja Adventista não se filie a partidos, mas mantenha fidelidade à sua mensagem, Costa menciona que a Igreja, nos Estados Unidos, sempre foi favorável aos republicanos, que adotam um sistema de governo visto pela denominação como o ideal. Não

${ }^{10}$ Ver White (2008, p. 280-287).

REVISTA RELEGENS THRÉSKEIA - 2021 - UFPR 
obstante, no caso do embate político em torno da observância do domingo, a Igreja se posicionou ao lado dos democratas, por estes defenderem que a liberdade religiosa seria ameaçada no caso em questão. As condições de produção dos discursos da IASD buscam resguardar sua liberdade religiosa, o que dá margem a alinhamentos com grupos com os quais a Igreja não possui afinidade. Observa-se que, por vezes, a preocupação dos adventistas se restringe aos impactos de decisões políticas que podem alcançar algum aspecto da esfera religiosa que lhes afetaria diretamente.

\subsection{Documento Os adventistas e a política}

O artigo Os adventistas e a política (DEPARTAMENTO..., 2014, p. 12-13), publicado na edição de setembro de 2014 da Revista Adventista, reproduz o documento homônimo produzido pelo Departamento de Liberdade Religiosa do escritório da Igreja Adventista para a América do Sul.

O documento Os adventistas e a política, ${ }^{11}$ que se baseia no capítulo A relação entre Igreja e Estado do Declarações da Igreja, ${ }^{12}$ adotado pela Associação Geral da IASD em março de 2002. A compreensão de política apresentada reflete os princípios já expostos no artigo de Timm (2006), com o acréscimo de orientações práticas para cada um dos três temas discutidos: os adventistas e a política partidária, os adventistas e as eleições e os adventistas e o relacionamento com candidatos adventistas.

Embora a Igreja não incentive a participação dos seus membros em partidos, nem se posicione contra ou a favor de qualquer regime ou partidos políticos, ela "reconhece seu papel dentro da sociedade como uma organização ativa e envolvida com questões pertinentes à cidadania.” (DEPARTAMENTO..., 2014, p. 12). Apresentam-se duas justificativas para a elaboração do material: servir "como um guia conciso e unificado a respeito do tema para que os membros compreendam o que pensa a organização" e "como referência para que políticos e partidos entendam como age a Igreja Adventista e não criem expectativas diferentes das que ela se propõe.” (DEPARTAMENTO..., 2014, p. 12).

A partir da memória discursiva, a IASD mantém uma regularidade discursiva sobre a relação de seus membros com a política através da repetição dos anunciados elaborados por Timm (2006), agora formalizados em um documento oficial da denominação na América do

\footnotetext{
11 Disponível em: <https://www.adventistas.org/pt/institucional/organizacao/declaracoes-e-documentosoficiais/os-adventistas-e-politica/>. Acesso em: 3 ago. 2021.

12 Disponível em: <http://deptos.adventistas.org.s3.amazonaws.com/institucional/pt/documento-policaportugues.pdf $>$. Acesso em: 30 set. 2018. 
Sul. O esforço que se apresenta está, pela paráfrase, na adição de elementos, as orientações práticas, especificadas em um manual na forma de práticas tidas como aceitáveis que sedimentam o discurso, como expresso na sequência, oriundo da tradição adventista, referenciado no carisma profética da instituição.

Assim como em Timm (2006), o documento destaca que as principais referências da Igreja para tratar de processos políticos são os capítulos Nossa atitude quanto à política do livro Obreiros evangélicos (WHITE, 2007c, 351-355) e trechos do Testemunho especial acerca de politica do Fundamentos da educação cristã (WHITE, 2007a, p. 415-425) de Ellen G. White; e repete fidedignamente os três princípios fundamentais que norteiam a posição da IASD sobre política já assinalados em Timm (2006): a separação entre Igreja e Estado, o de que o nível de justiça social de um país é proporcional ao nível de justiça de cada cidadão, e o de que ser cristão não isenta o cidadão de seus deveres civis - este tratado com menos ênfase no documento do que em Timm (DEPARTAMENTO..., 2014, p. 12).

As orientações práticas apresentadas quanto os adventistas e a política partidária são que:

1. A Igreja Adventista não apoia, não possui partidos políticos, nem repassa recursos a essas organizações por entender que adota uma postura não partidária. 2. A Igreja Adventista não permite que, em seus templos, sejam realizadas reuniões com finalidade político-partidária ou de cunho eleitoral. 3. A Igreja Adventista não mantém bancada de parlamentares em nível municipal, estadual, federal, nem de líderes políticos de quaisquer regiões administrativas ou demais países que fazem parte da Divisão Sul-Americana. (DEPARTAMENTO..., 2014, p. 12).

Em diferentes formulações dos mesmos espaços de dizer, pela paráfrase, o documento sistematiza, para todos os tópicos, as noções circulantes no meio adventista sobre a política partidária, por via da memória discursiva denominacional. Aqui, especificamente, se reforça o perfil apartidário adventista ao se explicitar que não domina ou sustenta financeira e ideologicamente partidos, bem como o impedimento à realização de ações político-partidárias de caráter eleitoral em seus espaços de cultos e o distanciamento da Igreja das bancadas e lideranças políticas e parlamentares em todas as esferas geográfico-administrativas na América do Sul.

Sobre os adventistas e as eleições, o documento reafirma que, para além da Bíblia, a Igreja usa como referência para o assunto os escritos de Ellen G. White (DEPARTAMENTO..., 2014 , p. 12) e recomenda que os membros privilegiem candidatos que promovam nas campanhas pautas similares às dos adventistas, como conceitos em favor da saúde, do uso equilibrado dos recursos naturais e do direito à liberdade de expressão religiosa 
(DEPARTAMENTO..., 2014, p. 13). Nas determinações que caracterizam o processo discursivo inerente às condições de produção, em que se mesclam as imagens do contexto em que o sujeito adventista está inserido e uma situação concreta, a necessidade posta de eleger representantes que apreciam e promovam pautas próximas ao adventismo, agrega-se outro referente destacado da teologia adventista para tal escolha, as crenças ligadas à criação, ${ }^{13}$ especificada na temperança ao apropriar-se dos recursos naturais do planeta.

As orientações práticas sobre a relação adventistas e eleições são que:

1. A Igreja Adventista recomenda que os membros participem das eleições em seus países desde que nessas ocasiões não haja nenhuma incompatibilidade com os princípios bíblicos defendidos pela igreja. 2. É orientado que os membros votem em candidatos que defendam os princípios de temperança, o que inclui combate ao fumo e bebidas alcoólicas; questões de liberdade de expressão religiosa, separação entre igreja e estado; e que efetivamente tenham propostas concretas para melhorar a qualidade de vida da população em geral, especialmente nas áreas de saúde, educação e família. Mas não há nenhuma orientação quanto a votar em candidatos de determinados partidos políticos. 3. Pastores, líderes locais ou profissionais adventistas não devem promover candidatos em cultos regulares ou demais programas oficiais da Igreja Adventista, tampouco nas sedes administrativas e instituições educacionais, de saúde ou sedes de projetos da ADRA ou mantidos de alguma forma pela organização adventista. A Igreja Adventista não apoia a mobilização para que sejam dados votos a determinado candidato. 4. É vedado o uso do dízimo para pagamento de qualquer pessoa para fazer discursos sobre questões políticas. (DEPARTAMENTO..., 2014, p. 13).

O funcionamento parafrástico do discurso documental opera para resgatar a regularidade discursiva e delimitar práticas dentro dos significados pré-construídos sobre o modo de agir esperado pela Igreja. Assim, a participação nas eleições se condiciona por condições propícias e harmônicas com o conjunto de normas bíblicas assimiladas pela Igreja. $\mathrm{Na}$ polissemia e, pois, reelaboração do discurso, agregam-se as noções de que tanto corpo eclesiástico quanto leigos estão desautorizados a impulsionar candidatos específicos, não só nas igrejas locais, mas em qualquer programa ou instituição administrada pela IASD; a destinar recursos financeiros considerados sagrados para ações discursivas sobre temas políticos; e, ao que parece mais a alteração mais expressiva na estrutura da filiação dos sentidos no tema, a recomendação de que se escolham candidatos que, para além de defender os mesmos princípios particulares da Igreja, estejam preocupados em transformar a vida das pessoas na saúde, educação e na família.

\footnotetext{
${ }^{13}$ Os adventistas compreendem que "cumpre-lhes conservar o meio ambiente [e] a necessidade de proteger a criação de Deus.” (BRADFORD, 2011, p. 739). 
Referente ao relacionamento com candidatos adventistas, como em Timm (2006), o documento defende o direito do cristão-adventista de exercer sua cidadania através da atuação em cargos políticos. As orientações práticas indicam que:

1. Candidatos adventistas não devem usar o púlpito nem programas oficiais da igreja para pedir votos. 2. É recomendado que os membros que se candidatam a cargos públicos eletivos deixem suas funções na igreja local no período da campanha. No caso de pastores e obreiros assalariados, é obrigatório que deixem seu trabalho na obra adventista antes mesmo de lançar suas candidaturas. 3. Adventistas com cargos eletivos não possuem autorização para falar em nome da Igreja Adventista em eventos, reuniões ou seminários. Também não são representantes da Igreja Adventista no parlamento ou poder executivo. São apenas membros da igreja com um cargo eletivo" (DEPARTAMENTO..., 2014, p. 13).

Na paráfrase do apartidarismo denominacional, se repete nos ditos sua consecução através da necessidade dos membros que participam de disputas político-eleitorais abandonarem suas funções denominacionais no momento da campanha, o que vale não só para empregados diretos da Igreja, mas para leigos, com a diferença que aqueles devem fazê-lo façam antes do início das disputas. Se eleitos, aos adventistas impede-se atuarem em nome da IASD nem colocarem-se enquanto representante dela nos espaços políticos.

\subsection{Discussão retomada}

Na edição de setembro de 2018, Helio Carnassale, diretor do Departamento de Liberdade Religiosa da sede sul-americana da Igreja Adventista, em Os adventistas e a política (CARNASSALE, 2018, p. 46), retoma as discussões do documento homônimo, publicado em 2014, um "guia conciso" destinado a pastores, funcionários e membros da IASD com recomendações da Igreja sobre as eleições que, no momento, estavam próximas de ocorrer em países sul-americanos, apoio partidário, candidaturas de membros e manifestações públicas.

Carnassale destaca que o documento não possui a pretensão de "substituir os conselhos divinos" e que as orientações nele presentes expressam o entendimento que a liderança da Igreja Adventista na América do Sul possui sobre o relacionamento da instituição com os poderes públicos e os assuntos políticos, assim como dos deveres dos membros da IASD enquanto cidadãos (CARNASSALE, 2018, p. 46).

Na memória discursiva, a estabilização se sucede na regularização do discurso das recomendações formatadas em um manual, compêndio que encerra conhecimentos basilares para o agir político dos adventistas. Além disso, a memória discursiva relembra que o dever da obediência não substitui as orientações divinas, mas reforça seus sentidos. 
De novidade em relação a Os adventistas e a política, Carnassale esclarece que sua elaboração foi resultado de um grupo de trabalho formado por administradores das sedes regionais da Igreja, advogados, comunicadores, educadores, jornalistas, pastores, sociólogos e teólogos, que se basearam em situações anteriormente enfrentadas pela IASD para propor procedimentos práticos, além de fazer a revisão final do documento. Considerado um tema sensível, garante-se que o trabalho ocorreu de modo a gerar um documento "equilibrado, claro e abrangente" que contemplou a realidade sociopolítica da América do Sul ao mesmo tempo em que seguiu as orientações do Manual da Igreja Adventista do Sétimo Dia (ASSOCIAÇÃO GERAL DA IGREJA ADVENTISTA DO SÉTIMO DIA, 2016) e as declarações oficiais da denominação. O documento, votado no Concílio Anual da DSA de 2017 agrega mais um tópico ao apresentado na Revista Adventista em 2014: os adventistas e as manifestações públicas. ${ }^{14} \mathrm{~A}$ tônica do artigo de Carnassale se expressa na recomendação que os adventistas assumam responsabilidades civis com seriedade e exerçam o papel de cidadãos "sem se esquecerem da cidadania celestial" (CARNASSALE, 2018, p. 46).

Destaca-se que o documento, ao considerar o contexto sociopolítico sul-americano que, como anteriormente discutido, vivencia um momento de intensa polarização política, preza pelo equilíbrio, o que expressa as condições de produção que demarcam o entendimento da Igreja sobre o tema. Assume-se, também, a memória discursiva ao utilizar-se dos preceitos do manual da IASD e da compreensão adventista de que a cidadania celestial de cada cristão sobressai à terrena, embora não se desconsidere esta última. As condições de produção da década de 2010, o crescimento de manifestações políticas públicas, desembocam na inclusão de mais um item ao texto, em uma polissemia do discurso.

Carnassale argumenta que a Bíblia motiva o respeito às autoridades e que os adventistas devem orar por elas, além de buscar o bem da sociedade. No plano político, a Igreja orienta que seus membros votem conforme a consciência individual, que escolham candidatos que defendam os princípios da qualidade de vida e da saúde, do chamado "modelo bíblico de família", dos valores éticos e morais, da liberdade religiosa e da separação entre Igreja e Estado.

\footnotetext{
${ }^{14} \mathrm{O}$ item indaga se os cristãos devem participar de manifestações públicas e se pastores, outros obreiros, aposentados com credencial especial e funcionários da Igreja podem sair às ruas e apoiar protestos populares. A Igreja garante respeitar o direito de expressão e reivindicações pacíficas e legítimas de ideias e ideais. A organização diz assumir um papel ativo na sociedade ao se envolver em questões relacionadas aos interesses e necessidades dos cidadãos através de atos missionários práticos e cita agências assistenciais, escolas, colégios e universidades, como organizações da Igreja que, em questões relacionadas a desigualdade e injustiça social, realizam projetos sociais e educacionais que beneficiam a vida comunitária. O documento especifica que a IASD age para defender suas convicções sem conflitar com os "princípios bíblicos" e sem se revoltar contra "ideologias" e as autoridades constituídas (DIVISÃO SUL-AMERICANA DA IGREJA ADVENTISTA DO SÉTIMO DIA, 2020).
} 
Embora reconheçam a legitimidade de governos e respeitem o direito do Estado de legislar em questões "seculares", consentido com as leis quando elas não contrariam "os preceitos bíblicos", sem desmerecer a importância das questões políticas, os adventistas compreendem que a função da Igreja se constitui em desenvolver práticas que fortaleçam a fé e promovam a esperança cristã na segunda vinda de Jesus. ${ }^{15}$ Ao reconhecer que o anúncio do evangelho implica ações solidárias de amor e minimização do sofrimento humano, creem que seus esforços devem se concentrar no serviço em prol da humanidade e o interesse na “salvação" delas (CARNASSALE, 2018, p. 46).

A memória discursiva adventista baseada em sua fundamentação na Bíblia como única regra de fé e crenças (VYHMEISTER, 2011, p. 1) aciona compreensões justificadas como seguimento do ordenamento divino para escolha de políticos que defendem a família conforme seu "modelo" bíblico, de obedecer leis aderentes às Escrituras para efetivar o mandato divino para a missão da Igreja, empregado na redenção humana, possível através da aplicação do evangelho às demandas humanas, que formam uma regularidade discursiva através do uso de sentidos pré-construídos.

\subsection{Postura para a escolha do voto}

Hora do voto, último artigo encontrado na revista, também de autoria de Helio Carnassale, e publicado em novembro de 2020, recupera os principais elementos do artigo de 2018 e responde qual deve ser a postura dos adventistas em relação à política e às eleições. Ao sinalizar que em eleições as tensões políticas crescem e as discussões ficam mais acaloradas, ele compreende o período como oportuno para relembrar certos "conselhos bíblicos" e a posição da IASD sobre o tema. Novamente, Carnassale aciona o documento Os adventistas e a política e esclarece que o texto votado em novembro de 2017 foi revisto em agosto de 2020 (CARNASSALE, 2020, p. 50). A revisão inclui um novo tópico que enfatiza o cuidado que os membros devem ter com manifestações políticas em redes sociais, além de alterações nas orientações sobre a participação de obreiros e pastores, da ativa e aposentados, em atividades partidárias (LEMOS, 2020, p. 36). ${ }^{16}$

\footnotetext{
${ }^{15}$ Para os adventistas, a volta de Jesus se constitui em uma doutrina central da Bíblia (LEHMANN, 2011, p. 988).

${ }^{16} \mathrm{O}$ documento indica que a discussão de temas político-partidários e as manifestações sobre partidos, candidatos e eleições nas mídias sociais geram não só debates, mas acusações como ofensas à honra, passíveis de penalidade penal, e a propagação de informações falsas. Para a IASD, a livre expressão do pensamento em questões políticas requer responsabilidade, pois podem resultar em consequências indesejáveis dependendo do conteúdo inadequado veiculado. Mesmo que as postagens e opiniões dos membros não reflitam o pensamento da Igreja, por vezes as manifestações individuais são avaliadas como se representassem o posicionamento oficial da organização sobre o assunto (DIVISÃO SUL-AMERICANA DA IGREJA ADVENTISTA DO SÉTIMO DIA, 2020). 
Enquanto que pela regularidade da memória discursiva se realçam o documento $O s$ adventistas e a política e recomendações da Bíblia consideradas como atinentes à política, depreende-se que as condições de produção refletem um contexto marcado por interações vigorosas, o que resulta em uma ampliação polissêmica do discurso, uma interpretação do posicionamento político dos adventistas que inclui a reflexão sobre manifestações em redes sociais. Surge, ainda, como elemento parafrástico, um dito que resgata a memória e retorna aos mesmos espaços do dizer, nas determinações sobre a participação política da liderança eclesiástica adventista.

Carnassale realça que a Igreja aconselha os membros a votarem de forma consciente nos candidatos que "promovam os valores bíblicos, o que resulta em benefícios para todos". Entre os valores que sustentam a postura da IASD sobre assuntos públicos sobressaem a "liberdade religiosa inclusiva" e a convicção da necessidade de separação entre Igreja e Estado. Ela acredita que a liberdade de religião para todos resulta em liberdade de pensamento, consciência e escolha dada por Deus para cada ser humano. De outro lado, a separação entre Igreja e Estado assegura a postura de não filiação e militância político-partidária seguida pela Igreja Adventista desde os primórdios de sua organização (CARNASSALE, 2020, p. 50). Pela paráfrase discursiva, o alcance da promoção de noções bíblicas não se limita aos adventistas, mas alcança todas as pessoas; da mesma forma, a liberdade religiosa, apresentada como inclusiva, ampliase para todos. Para a liderança da IASD, esses posicionamentos não geram conflitos com os poderes constituídos. São, porém, um reconhecimento da "ordem bíblica" para os cristãos de orar "em favor dos reis e de todos os que se acham investidos de autoridade" (1Tm 2,2) e do respeito ao princípio de que "não há autoridade que não proceda de Deus; e as autoridades que existem foram por ele instituídas" (Rm 13,1). Nos assuntos políticos, os adventistas defendem que devem se inspirar no que interpretam como o exemplo de Jesus. A partir disso, Carnassale usa um texto de Ellen G. White para orientar qual deve ser o comportamento dos adventistas (CARNASSALE, 2020, p. 50).

O governo sob que Jesus viveu era corrupto e opressivo; clamavam de todo lado os abusos - extorsões, intolerância e abusiva crueldade. Não obstante, o salvador não tentou nenhuma reforma civil. Não atacou nenhum abuso nacional, nem condenou os inimigos da nação. Não interferiu com a autoridade nem com a administração dos que se achavam no poder. Aquele que foi o nosso exemplo conservou-se afastado dos governos terrestres. Não porque fosse indiferente às misérias do homem, mas porque o remédio não residia em medidas meramente humanas e externas. (WHITE, 2007b, p. 443). 
Os escritos de Ellen G. White são, para a tradição adventista, uma manifestação do espírito de profecia. ${ }^{17}$ Atua para a memória discursiva que inspira a postura política dos membros da Igreja a construção feita por ele da imagem de Jesus como personagem - exemplar - sem pretensões políticas, pois as considerava incapazes de servir para a resolução dos problemas humanos, o que se encontra em aparente contradição à colocação de Costa (LIMA, 2010) de que Ellen G. White se mostrava favorável à aspiração dos jovens em ocupar funções políticas. Tal como no artigo de 2018, Carnassale explica que a IASD entende que a melhor forma de colaborar com os governantes se dá a partir da pregação do evangelho e do serviço às comunidades em que se encontra, o que a torna conhecida, relevante e confiável e que aos cristãos dar "a César o que é de César e a Deus o que é de Deus" significa cumprir seus deveres cidadãos, como o exercício do voto. Embora a IASD não lance nem patrocine ou indique candidatos, recomenda que seus membros votem em pessoas que promovam e defendam princípios praticados pelos adventistas, como a valorização da qualidade de vida e da saúde, da família, da liberdade religiosa e da separação entre Igreja e Estado (CARNASSALE, 2020, p. 50).

Quer-se legitimar a memória discursiva adventista sobre a relação dos cristãos com a política pelo recurso à autoridade, as Escrituras cristãs, na transposição direta de versículos ao tempo presente que refletiriam a vontade divina no tocante ao tema, e expressa uma postura de subserviência dos cristãos aos poderes estabelecidos. A atuação político-partidária dos adventistas se reduz à participação de eleições pelo voto.

\section{Considerações finais}

As referências para a compreensão dos adventistas sobre política estão em duas obras de Ellen G. White, figura de carisma profético para a IASD. Os escritos whiteanos norteiam a produção da primeira sistematização de orientações políticas aqui exposta (TIMM, 2006), que serve de base para a produção do documento Os adventistas e a política, cuja compreensão de política reflete-o, com o acréscimo de orientações práticas para cada dos temas centrais discutidos, em que princípios básicos sobre a postura desejava dos adventistas como cidadãos, candidatos e eleitores políticos são expressos. A memória discursiva adventista parte de elementos da tradição denominacional e do cristianismo. Da IASD, especificamente, do espírito

\footnotetext{
${ }^{17}$ A teologia adventista expressa em suas crenças fundamentais que as "Escrituras revelam que um dos dons do Espírito Santo é a profecia. Esse dom [...] foi manifestado no ministério de Ellen G. White. Seus escritos falam com autoridade profética e proveem consolo, orientação, instrução e correção para a igreja." (ASSOCIAÇÃO MINISTERIAL DA ASSOCIAÇÃO GERAL DOS ADVENTISTAS DO SÉTIMO DIA, 2016, p. 276).

REVISTA RELEGENS THRÉSKEIA - 2021 - UFPR
} 
de profecia; do cristianismo, da interpretação da Igreja sobre os ensinamentos de Jesus e de seus discípulos, e da tradição apostólica.

Três princípios fundamentais orientam a posição da IASD sobre política. O primeiro deles é a separação entre Igreja e Estado, em que cada qual deve buscar cumprir suas atribuições sem ultrapassar a esfera de ação da outra. O segundo princípio parte do pressuposto de que o nível da justiça social de um país está em equivalência ao nível de justiça de cada cidadão, e que este provém do interior de cada pessoa. O terceiro princípio se situa no entendimento de que cada cristão-adventista carrega uma dupla cidadania; primeiramente, cidadão do reino de Deus, mas, também, cidadão de seu país de origem.

Privilegia-se uma concepção de realidade que faz os adventistas dar mais peso a um mundo porvir, conforme suas crenças escatológicas. Isso pauta a relação dos membros com a política e a orientação de exercerem uma dupla cidadania, primeiro, de cidadãos do reino de Deus e, depois, de seus países de origem. A Igreja Adventista não se posiciona favorável ou contrária a qualquer regime ou partido político, postura mantida em todos os níveis da organização e nas diferentes instituições da Igreja, incluindo as congregações locais. $O$ aparente contrassenso da postura apolítica e apartidária com seu desejo da transformação da realidade leva a Igreja, pela memória discursiva de obediência aos ensinos que avalia bíblicos, a respeitar todas as pessoas e se relacionar pacificamente com governantes e partidos políticos.

Considera-se que ocupar cargos políticos está entre os direitos de todo cristão-adventista no exercício de sua cidadania. Mesmo que a IASD não estimule nem desencoraje a candidatura política de seus membros, ela entende que a sociedade pode ser beneficiada pelo bom exemplo de alguns políticos adventistas que participam do processo eleitoral de forma honesta e exercem seus mandatos de maneira digna, sem comprometerem princípios bíblicos. Destaca-se o quanto o trabalho de adventistas eleitos pode favorecer a Igreja. Orienta-se que as programações oficiais de qualquer congregação adventista não sejam usadas como palanque político que afete a postura apolítica da denominação.

As condições de produção do discurso adventista sobre a política partidária admitem a instrumentalização da política para fins benéficos à Igreja. Assim, implicitamente encoraja-se a candidatura de seus membros comprometidos com valores bíblicos. O princípio básico indicado aos adventistas para a escolha de seus representantes constitui-se em votar nos candidatos cuja ideologia, crenças, estilo de vida e propostas políticas estejam mais próximos dos princípios adventistas. As condições de produção mostram, também, a intencionalidade da 
Igreja em apoiar candidatos que defendam valores próximos ou especificamente adventistas, como a garantia da observância do sábado.

As condições de produção, ainda, que incluem o contexto sócio-histórico brasileiro da última década, de intensa polarização política e atuação expressiva de políticos ligados a grupos religiosos na defesa de "valores cristãos" como a "família", ao que parece, influenciou a discussão da política partidária na Revista Adventista, visto que quatro (LIMA, 2010; DEPARTAMENTO..., 2014; CARNASSALE, 2018; CARNASSALE, 2020) dos cinco textos encontrados foram publicados a partir de 2010.

O tripé que sustenta a memória discursiva adventista sobre o tema é formado por referências bíblicas, escritos de Ellen G. White e o documento Os adventistas e a política. O último ganha destaque na medida em que aglutina a memória dos demais e se constitui na referente mais acionado pelo periódico ao tratar da política partidária. Pela polissemia discursiva, agregam-se novas discussões ao documento original de 2014, os adventistas e as manifestações em mídias sociais e os adventistas e as manifestações públicas, que ampliam a compreensão e recomendações da Igreja sobre o tema.

O desafio que se apresenta de pesquisas ulteriores para compreensão e relação dos adventistas com a política se encontra em outras análises da Revista Adventista e de outros periódicos adventistas, a partir de tópicos como política, de forma ampla, além de política eleitoral, eleições, eleitores e partidos políticos. Outro esforço de pesquisa oportuno a ser realizado está na recepção do tema política para os membros da Igreja. Uma investigação nesse sentido pode se concentrar nos perfis de redes sociais de grupos de membros que se alinham e fazem a defesa das crenças e práticas da IASD e o dos grupos que criticam e reformulam crenças e práticas adventistas.

\section{Referências}

ASSOCIAÇÃO GERAL DA IGREJA ADVENTISTA DO SÉTIMO DIA. A relação entre Igreja e Estado. In: ASSOCIAÇÃO GERAL DA IGREJA ADVENTISTA DO SÉTIMO DIA. Declarações da Igreja: aborto, assédio sexual, homossexualismo, clonagem, ecumenismo e outros temas atuais. 3. ed. Tatuí: Casa Publicadora Brasileira, 2012. p. 154-160.

ASSOCIAÇÃO GERAL DA IGREJA ADVENTISTA DO SÉTIMO DIA. Manual da Igreja Adventista do Sétimo Dia. 22. ed. Tatuí: Casa Publicadora Brasileira, 2016.

ASSOCIAÇÃO MINISTERIAL DA ASSOCIAÇÃO GERAL DOS ADVENTISTAS DO SÉTIMO DIA. Nisto cremos: as 28 crenças fundamentais da Igreja Adventista do Sétimo Dia. 9. ed. Tatuí: Casa Publicadora Brasileira, 2016. 
BARBOSA, Allan W. S. Na cova dos leões: conflitos e contradições entre adventismo e política. In: SEMINÁRIO DE ANTROPOLOGIA SOCIAL DA UFSCAR, 1., 2012, São Carlos. Anais... São Carlos: UFSCar, 2012. Disponível em: <http://www.seminariodeantropologia.ufscar.br/wp-content/uploads/2014/09/ANAIS-DO-IIIsemin\%C3\%A1rio-de-antropologia-pdf.714-725.pdf>. Acesso em: 3 ago. 2021.

BEACH, Bert B. Igreja Adventista do Sétimo Dia. In: LOSSKY, Nicholas et al. (Eds.). Dicionário do movimento ecumênico. Petrópolis: Vozes, 2005. p. 609-610.

BRADFORD, Charles E. Mordomia. In: DEDEREN, Raoul (Ed.). Tratado de teologia: adventista do sétimo dia. Tatuí: Casa Publicadora Brasileira, 2011. p. 721-747.

CARNASSALE, Helio. Hora do voto. Revista Adventista, Tatui, ano 115, n. 1363, p. 50, nov. 2020.

CARNASSALE, Helio. Os adventistas e a política. Revista Adventista, Tatuí, ano 113, n. 1337, p. 46, set. 2018.

CARRANZA, Brenda; SANTOS, Renan W.; JÁCOMO, Luiz. Dimensões religiosas da radicalização política no Brasil contemporâneo. Plural, São Paulo, v. 28, n. 1, p. 5-16, jan./jun. 2021. Disponível em: <https://www.revistas.usp.br/plural/article/view/188499/174215>. Acesso em: 3 ago. 2021.

CELLARD, André. A análise documental. In: POUPART, Jean et al. A pesquisa qualitativa: enfoques epistemológicos e metodológicos. Petrópolis: Vozes, 2008. p. 295-316.

DE BENEDICTO, Marcos; BORGES, Michelson. Um século de história. Revista Adventista, Tatuí, ano 101, n. 1, p. 8-13, jan. 2006.

DEPARTAMENTO DE LIBERDADE RELIGIOSA DA DIVISÃO SUL-AMERICANA DA IGREJA ADVENTISTA DO SÉTIMO DIA. Os adventistas e a política. Revista Adventista, Tatuí, ano 109, n. 1276, p. 12-13, set. 2014.

DIVISÃO SUL-AMERICANA DA IGREJA ADVENTISTA DO SÉTIMO DIA. Os adventistas e a política. Brasília, 2020. Disponível em: $<$ https://www.adventistas.org/pt/institucional/organizacao/declaracoes-e-documentosoficiais/os-adventistas-e-politica/> . Acesso em: 3 ago. 2021.

DUTRA, Roberto; PESSÔA, Karine. Guerras culturais e a relação entre religião e política no Brasil contemporâneo. Revista Brasileira de História das Religiões, Maringá, ano 13, n. 39, p. 233-256, jan./abr. 2021. Disponível em: <https://periodicos.uem.br/ojs/index.php/RbhrAnpuh/article/view/54621/751375151520>. Acesso em: 3 ago. 2021.

FONSECA, Alexandre B. Muito além do sábado: o pioneirismo adventista na mídia eletrônica religiosa. Revista de Estudos da Religião, São Paulo, ano 8, n. 3, p. 89-100, jul./set. 2008. Disponível em: <http://www.pucsp.br/rever/rv3_2008/t_fonseca.pdf>. Acesso em: 3 ago. 2021.

FONSECA, André D.; MARIN, Jérri R. Introdução. In: FONSECA, André D.; MARIN, Jérri R. (Orgs.). História, imprensa e religião. Curitiba: Appris, 2020. p. 9-16. 
FUCKNER, Ismael. A Igreja Adventista do Sétimo Dia entre a modernidade e a pósmodernidade. Mosaico, Goiânia, v. 5, n. 2, p. 159-169, jul./dez. 2012. Disponível em: <http://seer.ucg.br/index.php/mosaico/article/viewPDFInterstitial/2501/1556>. Acesso em: 3 ago. 2021.

FURTADO, Kevin W. K. A interpretação na Igreja adventista brasileira da teologia ecumênica conciliar: o Vaticano II e o ecumenismo nas páginas da Revista Adventista (1962-1965). Interações, Belo Horizonte, v. 14, n. 26, p. 275-296, jul./dez. 2019. Disponível em: <http://periodicos.pucminas.br/index.php/interacoes/article/view/18125/16434>. Acesso em: 3 ago. 2021.

FURTADO, Kevin W. K. Adventistas: representações escatológico-sabático-dietéticas. São Paulo: Fonte Editorial, 2017.

GALLEGO, Esther S.; ORTELLADO, Pablo; MORETTO, Márcio. Guerras culturais e populismo antipetista nas manifestações apoio à Operação Lava Jato e contra a reforma da previdência. Em Debate, Belo Horizonte, v. 9, n. 2, p. 35-45, ago. 2017. Disponível em: <http://opiniaopublica.ufmg.br/site/files/artigo/7.pdf>. Acesso em: 3 ago. 2021.

LEHMANN, Richard P. A segunda vinda de Jesus. In: DEDEREN, Raoul (Ed.). Tratado de teologia: adventista do sétimo dia. Tatuí: Casa Publicadora Brasileira, 2011. p. 988-1023.

LEMOS, Felipe. Indicadores do discipulado. Revista Adventista, Tatuí, ano 115, n. 1361, p. 36, set. 2020.

LIMA, Fábio B. Entre bolhas e grietas: a polarização político-ideológica nas redes sociais. Estudos Linguísticos e Literários, Salvador, n. 67, p. 63-81, jul./dez. 2020. Disponível em: <https://periodicos.ufba.br/index.php/estudos/article/view/44100/24340>. Acesso em: 3 ago. 2021.

LIMA, Wendel. Dupla cidadania. Revista Adventista, Tatuí, ano 105, n. 1225, p. 6-7, jun. 2010.

MARIANO, Ricardo; GERARDI, Dirceu A. Eleições presidenciais na América Latina em 2018 e ativismo político de evangélicos conservadores. Revista USP, São Paulo, n. 120, p. 61-76, jan./mar. 2019.

Disponível

em: <https://www.revistas.usp.br/revusp/article/view/155531/151189>. Acesso em: 3 ago. 2021.

NAVARRO, Juan B. Dicionário de ecumenismo. 10. ed. Aparecida: Santuário, 2006.

NOVAES, Allan. O problema adventismo-televisão: uma análise do pensamento adventista sobre a TV a partir da tipologia de H. Richard Niebuhr em Cristo e cultura. 2016, $323 \mathrm{f}$. Tese (Doutorado em Ciência da Religião) - Programa de Estudos Pós-Graduados em Ciência da Religião, Pontifícia Universidade Católica de São Paulo, São Paulo, 2016.

OLIVEIRA, Maria M. Como fazer pesquisa qualitativa. Petrópolis, Vozes, 2007. 
OLIVEIRA FILHO, José J. Formação histórica do movimento adventista. Estudos avançados, São Paulo, v. 18, n. 52, p. 157-179, set./dez. 2004. Disponível em: <http://www.scielo.br/pdf/ea/v18n52/a12v1852.pdf>. Acesso em: 3 ago. 2021.

PAIVA JÚNIOR, Geová S. A construção identitária dos jovens adventistas do sétimo dia: dilemas e conflitos no espaço público. In: ENCONTRO DE CIÊNCIAS SOCIAIS DO NORTE E NORDESTE, 15., 2012, Teresina. Anais... Teresina: UFPI, 2012. Disponível em: <http://www.sinteseeventos.com.br/ciso/anaisxvciso/resumos/GT19-27.pdf>. Acesso em: 3 ago. 2021.

PY, Fábio; SILVEIRA, Emerson S.; FREITAS, Marcos V. R. Os cristãos e a política no Brasil contemporâneo: laicidade em disputa, Estado em colapso, religião em efervescência. Revista Brasileira de História das Religiões, Maringá, ano 13, n. 39, p. 5-12, jan./abr. 2021. Disponível em: <https://periodicos.uem.br/ojs/index.php/RbhrAnpuh/article/view/57228/751375151510>. Acesso em: 3 ago. 2021.

RIBEIRO, Lidice M. P. O protestantismo brasileiro: objeto em estudo. Revista USP, São Paulo, n. $73, \quad$ p. 117-129, mar./maio 2007. Disponível em: <www.revistas.usp.br/revusp/article/download/13593/15411>. Acesso em: 3 ago. 2021.

ROCHA, José M. A responsabilidade do adventista e da IASD no contexto político. Kerygma, Engenheiro Coelho, v. 2, n. 2, p. 11-19, jul./dez. 2006. Disponível em: <https://revistas.unasp.edu.br/kerygma/article/view/290/294>. Acesso em: 3 ago. 2021.

SCHEFFEL, Rubem M. A importância da imprensa. Revista Adventista, Tatuí, ano 101, n. 1, p. 16-17, jan. 2006.

SCHWARZ, Richard W.; GREENLEAF, Floyd. Portadores de luz: história da Igreja Adventista do Sétimo Dia. Engenheiro Coelho: Unaspress, 2009.

SEAMAN, John. Quem são os adventistas do sétimo dia? Um breve exame de sua história, crenças, povo, Igreja e missão. 5. ed. Tatuí: Casa Publicadora Brasileira, 2011.

TIMM, Alberto R. Os adventistas e a política. Revista Adventista, Tatuí, ano 101, n. 5, p. 12 15, maio 2006.

VYHMEISTER, Nancy J. Quem são os adventistas do sétimo dia? In: DEDEREN, Raoul (Ed.). Tratado de teologia: adventista do sétimo dia. Tatuí: Casa Publicadora Brasileira, 2011. p. 125.

WHITE. Ellen G. Fundamentos da educação cristã. Silver Spring: Ellen G. White Estate, 2007a. Disponível em: <http://www.centrowhite.org.br/files/ebooks/egw/Fundamentos\%20da\%20EducaÃ $\tilde{A} £ o \% 20$ Crist ̃̂£.pdf>. Acesso em: 30 set. 2018.

WHITE, Ellen G. O desejado de todas as nações. Silver Spring: Ellen G. White Estate, 2007b. Disponível 
<http://www.centrowhite.org.br/files/ebooks/egw/O\%20Desejado\%20de\%20Todas\%20as\%2 0Na\%C3\%A7\%C3\%B5es.pdf>. Acesso em: 3 ago. 2021.

WHITE. Ellen G. Obreiros evangélicos. Silver Spring: Ellen G. White Estate, 2007c. Disponível

em: <http://www.centrowhite.org.br/files/ebooks/egw/Obreiros\%20Evang\%C3\%83\%C2\%A9licos .pdf>. Acesso em: 30 set. 2018.

WHITE. Ellen G. Testemunhos para ministros e obreiros evangélicos. Silver Spring: Ellen G. White Estate, 2008. Disponível em: $<$ http://www.centrowhite.org.br/files/ebooks/egw/Testemunhos\%20para\%20Ministros\%20e\% 20Obreiros\%20Evang\%C3\%83\%C2\%A9licos.pdf>. Acesso em: 7 out. 2018. 